\title{
Pengaruh Pembelajaran PAI Menggunakan Aplikasi Whatsapp terhadap Prestasi Belajar Siswa di SD Negeri 14 Sitiung
}

\author{
Desmalinda', Rahmi Wiza ${ }^{2}$ \\ desmalinda80@gmail.com ${ }^{1}$, rahmiwiza@fis.unp.ac.id ${ }^{2}$ \\ Universitas Negeri Padang12
}

\begin{tabular}{l}
\hline ARTICLE INFO \\
\hline Article history: \\
Received 5 Agustus 2021 \\
Revised 24 Agustus 2021 \\
Accepted $31 \quad$ Agustus \\
2021
\end{tabular}

Keywords:

Pembelajaran PAI,

Whatsapp, Prestasi

Belajar

\section{Clonflict of Interest:}

None

\section{Funding:}

None

\begin{abstract}
Penelitian in

dilatarbelakangi oleh

pembelajaran daring yang dilakukan di SD Negeri 14 Sitiung. Penelitian ini bertujuan untuk menjelaskan proses pembelajaran daring di SD Negeri 14 Sitiung dan untuk mengetahui adakah pengaruh pembelajaran PAI menggunakan aplikasi whatsapp terhadap prestasi belajar siswa di SD Negeri 14 Sitiung, Penelitian ini menggunakan pendekatan kuantitatif dengan jenis penelitian korelasional. Pengambilan sampel dilakukan dengan teknik purposive sampling. Untuk uji hipotesis peneliti menggunakan analisis data regresi linear sederhana dengan uji $\mathrm{T}$ dan Koefisien determinasi. Hasil uji $\mathrm{T}$ menunjukan nilai $\mathrm{t}$ tabel $-0,348<\mathrm{t}$ hitung 1,690 dan nilai signifikannya $0,730>0,05$, maka dapat disimpulkan bahwa hipotesis $\mathrm{HO}$ diterima dan hipotesis Ha ditolak. Hal ini menunjukan bahwa tidak terdapat pengaruh yang signifikan antara pembelajaran PAI menggunakan aplikasi whatsapp dengan prestasi belajar siswa di SD Negeri 14 Sitiung.
\end{abstract}

Corresponding Author: Desmalinda, Department Islamic Education, Faculty of Social Science, Universitas Negeri Padang, Indonesia, Email: desmalinda80@gmail.com Phone: +62852-6356-9510

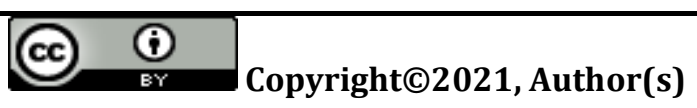

\section{Pendahuluan}

Covid-19 adalah musibah yang memilukan seluruh penduduk yang ada di dunia. kehidupan manusia terganggu, baik bidang ekonomi maupun pendidikan. Beberapa negara memutuskan untuk menutup sekolah, perguruan tinggi, begitupun Indonesia (Aji, 2020).

Pada tahun 2020 virus Covid-19 memberikan dampak yang luar biasa terhadap semua bidang, termasuk bidang pendidikan. Proses pembelajaran yang awalnya tatap muka berubah menjadi pembelajaran jarak jauh. Walaupun demikian guru tetap harus melaksanakan kewajibannya sebagai seorang pendidik 
yaitu memastikan siswa tetap memperoleh ilmu pengetahuan dengan semaksimal mungkin (Aulia, 2020). Pembelajaran jarak jauh ini telah dimulai semenjak tanggal 16 maret 2020, khususnya di Indonesia.

Pembelajaran daring sama seperti pembelajaran tatap muka memerlukan perencanaan, pelakasanaan dan evaluasi, bukan hanya sekedar memberikan materi, memberikan soal-soal yang dikirimkan melalui aplikasi pembelajaran saja.

Menurut Dewi (2020) pembelajaran daring memerlukan bimbingan dari guru dan juga orangtua. Pembelajaran daring dilakukan menggunakan aplikasi pembelajaran seperti Zoom, Google Classroom, Group whatsapp dan aplikasi serupa lainnya.

Berdasarkan observasi dilapangan dengan wali kelas V Ibuk Novri Wanti, S.Pd tanggal 14 desember 2020, proses pembelajaran daring semester ganjil tahun 2020/2021 dilakukan secara daring sepenuhnya dengan hasil belajar siswa kelas VI dengan rata-rata nilai mid 76 dan rata-rata nilai raport 88,75. Berdasarkan wawancara dengan wali kelas V pada tanggal 02 Maret 2021 proses pembelajaran daring di SD Negeri 14 Sitiung semester genap tahun ajaran 2020/2021 sistemnya peserta didik dibagi menjadi 2 sesi, sesi pertama peserta didik absensi 1-10 hari senin tatap muka dan peserta didik absensi 11-20 daring dirumah begitupun sebaliknya. Alokasi pembelajaran pun berubah yang awalnya $1 \times 40$ menit menjadi 1x30 menit. Aplikasi yang digunakan dalam pembelajaran daring di SD Negeri 14 Sitiung adalah whatsapp group.

Penelitian ini bertujuan untuk menjelaskan bagaimana proses pembelajaran daring di SD Negeri 14 Sitiung dan adakah pengaruh pembelajaran PAI menggunakan aplikasi whatsapp terhadap prestasi belajar siswa di SD Negeri 14 Sitiung.

Perbedaan penelitian ini dengan penelitian sebelumnya ialah penelitian Achmad Chairudin yang berjudul "Pengaruh Pembelajaran Online terhadap Prestasi Siswa Kelas 5 Dan 6 MI Ma'arif Gedangan, Kec Tuntang, Kab Semarang tahun Ajaran 2020/2021" memiliki kaitan dengan penelitian ini yaitu kaitan persamaannya terletak pada variabel (Y) Prestasi belajar siswa dan memiliki perbedaan variabel yang diteliti yaitu variabel $(X)$ pembelajaran PAI menggunakan aplikasi whatsapp.

\section{Tinjauan Pustaka}

\section{Bentuk pembelajaran PAI}

\section{a. Pembelajaran Luring}

Menurut Sunender, dkk (2020) luring merupakan akronim dari luar jaringan yang terputus dari jejaring komputer. Luring juga bisa dikatakan sebagai pembelajaran sistem offline. Pembelajaran luring ialah pembelajaran tatap muka seperti yang dilaksakan sebelum pandemi melanda.

\section{b. Pembelajaran Daring}

Daring dalam KBBI Kemendikbud ialah akronim dari dalam jaringan, maksudnya terhubung melalui jejaring komputer, internet dan sebagainya. Pembelajaran daring adalah metode pembelajaran yang menggunakan model interaktif berbasis internet dan Learning Manajemen System. Aplikasi yang digunakan dalam pembelajaran daring dapat berupa Zoom, Whatsapp, Google Meet dan aplikasi pembelajaran lainnya. 
Menurut Permendikbud NO. 109/2013 proses pembelajaran yang menggunakan media komunikasi dan dilakukan secara jarak jauh disebut pendidikan jarak jauh. Pembelajaran daring ialah sebuah program penyelenggaraan kelas pembelajaran dalam jaringan yang digunakan untuk menjangkau kawasan yang lebih luas (Bilfaqqih \& Qamarudin, 2015:1).

Dari pengertian yang telah dipaparkan diatas, disimpulkan bahwa pembelajaran daring ialah pembelajaran yang mempergunakan dan memanfaatkan teknologi internet dalam proses pembelajarannya. Pembelajaran yang bisa dilakukan dimana dan kapan saja yang terpenting terhubung dengan jaringan internet.

1) Karakteristik Pembelajaran Daring

Menurut Tung dalam Mustofa, Chodzirin \& Sayekti (2019:154)

Pembelajaran daring memiliki ciri-ciri sebagai berikut:

i. Materi diberikan dalam bentuk teks, gambar dan lainnya.

ii. Komunikasi dilakukan secara bersamaan, contohnya menggunakan Zoom, Whatsapp grup, Google Meet dan aplikasi serupa lainnya.

iii. Materi pembelajaran mudah diperbaharui.

iv. Meningkatkan interaksi antar siswa maupun guru dengan siswa.

v. Pembelajaran yang dilaksanakan secara virtual.

vi. Bentuk komunikasi belajar bisa secara formal dan informal.

vii. Sumber belajar tidak hanya terfokus pada buku pelajaran saja tetapi juga bisa didapatkan melalui internet.

2) Manfaat pembelajaran daring

Menurut Bilfaqih \& Qomarudin (2015:4) ada beberapa manfaat dari pembelajaran daring diantaranya:

i. Dengan memanfaatkan multimedia dengan efektif dalam pembelajaran dapat meningkatkan mutu pendidikan.

ii. Melalui penyelenggaraan pembelajaran dalam jaringan dapat meningkatkan keterjangkauan pendidikan dan pelatihan yang bermutu.

iii. Melalui pemanfaatan sumber daya bersama dapat menekan biaya pendidikan dan pelatihan yang bermutu.

\section{Aplikasi Whatsapp}

\section{a. Pengertian Whatsapp}

Whatsapp adalah aplikasi yang ada dalam smartphone yang membolehkan kita saling berkirim pesan tampa biaya SMS, karena whatsapp ialah aplikasi yang memerlukan paket data internet sama seperti google, email dan lainnya. Aplikasi whatsapp memerlukan paket data atau wifi untuk melakukan obrolan online, saling bertukar foto, dan berbagi file kepada sesama.

Awalnya whatsapp hanya digunakan untuk mengirim pesan saja, namun seiring berkembangnya waktu whatsapp dilengkapi dengan fitur fitur menarik seperti berbagi foto dan vidio, berbagi kontak, berbagi lokasi terkini, berbagi file, berbagi pesan suara, panggilan telepon dan suara serta panggilan vidio. Whatsapp story merupakan salah satu fitur terbaru yang diberikan whatsapp, dimana kita bisa melihat cerita yang dibagikan seseorang sampai 24 jam. 
Desmalinda dan Rahmi Wiza: Pengaruh Pembelajaran PAI Menggunakan Aplikasi Whatsapp...

Menurut Pranajaya Wicaksosno (2018) whatsapp berasal dari kalimat whats dan up yang digunakan untuk menanyakan kabar seseorang. Pada tahun 2009 whatsapp didirikan oleh seorang pegawai Yahoo yang bernama Jan Koum dan Brian Acton.

\section{b. Fitur-fitur unggulan whatsapp}

Sama halnya dengan aplikasi lain, whatsapp juga memiliki fitur-fitur yang dapat digunakan oleh pengguna sesuai dengan jenis dan fungsinya masingmasing, diantaranya :

1) Foto dan vidio

Fitur ini merupakan fitur yang paling favorit dikarenakan pengguna dapat berkirim foto dan vidio dengan cepat. Seorang ibu dapat melihat foto dan vidio anaknya walaupun dalam keadaan berjauhan.

2) Panggilan vidio dan suara

Dengan menggunakan fitur ini, pengguna bisa berbicara seperti menelpon biasa tanpa dikenakan biaya panggilan. Bahkan pengguna dapat melalukan percakapan tatapmuka dengan oranglain (video call).

3) Pesan suara

Dengan menggunakan fitur ini, pengguna dapat mengirim rekaman suara dan juga mengatakan sesuatu dengan satu ketukan. Pesan suara biasanya dilakukan untuk menyapa seseorang. Pesan suara tetap dapat diputar secara berulang-ulang asalkan filenya masih ada dalam perangkat seluler.

4) Fitur dokumen

Fitur ini merupakan fitur yang paling diminati oleh mahasiswa, pelajar maupun pekerja kantor untuk mengirimkan file dokumen, word, exel, FDF dan lainnya. Pengguna bisa dengan mudah berbagi file tanpa harus menggunakan email atau aplikasi berbagi file lainnya.

\section{c. Fungsi dan manfaat whatsapp}

Sama halnya dengan aplikasi lain whatsapp juga memiliki kelebihan fungsi dan manfaat yaitu :

1) Whatsapp mempunyai fitur yang komplit. Contohnya pengguna bisa saling berkirim pesan, berbagi lokasi, bertukar foto dan vidio.

2) Whatsapp memiliki fasilitas grup chat.

3) Whatsapp dapat menghemat baterai dengan cara hanya aktif ketika ada pesan yang masuk saja.

4) Aplikasi ini sudah terintegrasi kedalam sistem, sama seperti SMS.

Whatsapp juga memiliki manfaat yaitu menjadikan seseorang dapat berkomunikasi walaupun tanpa harus betemu langsung, apalagi pada saat pandemi ini. Selain itu seseorang atau kelompok dapat berkomunikasi didalam sebuah grup whatsapp.

\section{d. Macam-macam isi pesan whatsapp}

Ada beberapa macam isi pesan dalam whatsapp diantaranya :

1) Pesan pendidikan

Isi pesan ini berupa pengiriman file-file tugas, materi dan juga kuis yang dikirimkan melalui fitur dokumen yang ada di whatsapp.

2) Pesan informasi

Yaitu pesan yang dikirimkan berupa berita terkini atau pun informasi penting. 
3) Pesan hiburan

Yaitu pesan berupa canda gurauan antara satu orang dengan yang lain, oleh karena itu whatsapp memberikan fitur chat dengan emoji, stiker, foto, lagu dan lainnya.

\section{Prestasi Belajar}

\section{a. Pengertian prestasi belajar}

Prestasi ialah hasil yang dicapai oleh seseorang dalam suatu kegiatan. Muhibbin Syah (2010:150) menjelaskan bahwa prestasi ialah suatu tingkat keberhasilan seseorang dalam mencapai tujuan yang telah ditetapkannya. Prestasi dari setiap individu itu berbeda-beda. Prestasi merupakan kemampuan yang diperoleh oleh seseorang setelah melakukan kegiatan pembelajaran (Mulyono Abdurrohman, 2003:37).

\section{b. Faktor-faktor yang mempengaruhi prestasi belajar}

Ada beberapa faktor yang mempengaruhi prestasi belajar (Ngalim Purwanto, 2010:107) diantaranya :

1) Faktor yang berasal dari dalam individu

Yaitu faktor psikologis dan fisiologis. Faktor psikologis ialah kemampuan kognitif, kecerdasan, bakat dalam diri dan lain sebagainya. Faktor fisiologis ialah kondisi panca indera dan jasmani seseorang.

2) Faktor yang berasal dari luar individu

Yaitu faktor instrumental dan faktor lingkungan. faktor instrumental berupa kurikulum, bahan ajar, sarana dan prasarana, dan lain sebagainya. Faktor lingkungan tersebut bisa lingkungan alam maupun lingkungan sosialnya.

\section{Metodologi}

Penelitian ini menggunakan pendekatan kuantitatiif dengan jenis korelasional. Populasi penelitian adalah siswa SD Negeri 14 Sitiung yang berjumlah 231 orang. Sampel penelitian siswa kelas $\mathrm{V}$ yang berjumlah 36 orang. Pengambilan sampel dilakukan dengan teknik purposive sampling. Data dikumpulkan dengan angket menggunakan skala likert. Untuk uji hipotesis menggunakan analisis data regresi linier sederhana dengan uji T.

\section{Hasil dan Pembahasan}

\section{A. Hasil}

\section{Proses Pembelajaran Daring}

a Pembukaan Pembelajaran

Pada proses ini siswa diminta untuk melakukan absensi kehadiran pada saat pembelajaran dengan cara menuliskan namanya di grup whatsapp secara berututan. Kegiatan ini dilakukan setiap kali pertemuan tidak hanya pada pertemuan pertama.

b Kegiatan Inti

Pada proses ini, guru membagikan materi pembelajaran melalui grup whatsapp dimana materi pembelajarannya berbentuk vidio guru yang sedang menjelaskan pembelajaran ataupun vidio yang diambil dari youtobe yang sesuai buku tema atau buku pembelajaran kelas $\mathrm{V}$, setelah itu guru memberikan waktu kepada siswa untuk bertanya apakah sudah memahami 
instruksi ataupun materi yang telah dibagikan guru kepada siswanya. Grup whatsapp ini tidak hanya digunakan untuk berbagi link saja tapi juga digunakan untuk berdiskusi tentang materi pembelajaran yang tidak dipahami oleh siswa.

\section{c Penutup}

Pada proses ini guru memberikan evaluasi terhadap materi pembelajaran yang telah disampaikan melalui grup whatsapp kepada siswanya, selanjutnya siswa diberikan tugas untuk materi pada hari tersebut dan dikumpulkan setiap hari jum'at ke sekolah dengan tetap mematuhi protokol kesehatan. Media whatsapp yang digunakan berbasis teks, gambar dan vidio.

\section{Pengaruh pembelajaran PAI menggunakan aplikasi whatsapp terhadap prestasi belajar siswa di SD Negeri 14 Sitiung}

Berdasarkan hasil pengujian hipotesis penelitian terlihat pada tabel berikut.

\begin{tabular}{|c|c|c|c|c|c|c|}
\hline \multicolumn{7}{|c|}{4.10 Uji Parsial (uji T) } \\
\hline \multirow{2}{*}{\multicolumn{2}{|c|}{ Model }} & \multicolumn{2}{|c|}{$\begin{array}{l}\text { Unstandardize } \\
\text { d Coefficients }\end{array}$} & \multirow{2}{*}{$\begin{array}{c}\text { Standardi } \\
\text { zed } \\
\text { Coefficien } \\
\text { ts } \\
\text { Beta }\end{array}$} & \multirow[t]{2}{*}{$\mathrm{T}$} & \multirow[t]{2}{*}{ Sig. } \\
\hline & & B & $\begin{array}{l}\text { Std. } \\
\text { Error }\end{array}$ & & & \\
\hline 1 & (Constant) & $\begin{array}{r}53,28 \\
1\end{array}$ & 10,498 & & $\begin{array}{r}5,07 \\
6\end{array}$ & ,000 \\
\hline & $\begin{array}{l}\text { Pembelaja } \\
\text { ran PAI } \\
\text { mengguna } \\
\text { kan } \\
\text { aplikasi } \\
\text { whatsapp }\end{array}$ &,- 080 & ,230 &,- 060 & - & ,730 \\
\hline
\end{tabular}

Setelah dilakukan pengujian menggunakan uji parsial (Uji T) diperoleh t tabel nya 1,690, nilai t hitung $-0,348<t$ tabel 1,690 dan nilai signifikansinya sebesar $0,730>0,05$ maka dapat disimpulkan hasil uji $\mathrm{T}$ penelitian ini hipotesis $\mathrm{HO}$ diterima dan Ha ditolak. Maka dapat disimpulkan bahwa tidak terdapat pengaruh yang signifikan pembelajaran PAI menggunakan aplikasi whatsapp terhadap prestasi belajar siswa di SD Negeri 14 Sitiung.

\section{Simpulan}

1. Proses pembelajaran daring di SD Negeri 14 Sitiung

a. Pembukaan Pembelajaran

Pada proses ini siswa diminta untuk melakukan absensi kehadiran pada saat pembelajaran dengan cara menuliskan namanya di grup whatsapp secara berututan.

b. Kegiatan Inti 
Pada proses ini, guru membagikan materi pembelajaran melalui grup whatsapp dimana materi pembelajarannya berbentuk vidio guru yang sedang menjelaskan pembelajaran ataupun vidio yang diambil dari youtobe yang sesuai buku tema atau buku pembelajaran kelas $\mathrm{V}$, setelah itu guru memberikan waktu kepada siswa untuk bertanya apakah sudah memahami instruksi ataupun materi yang telah dibagikan guru kepada siswanya.

c. Penutup

Pada proses ini guru memberikan evaluasi terhadap materi pembelajaran yang telah disampaikan melalui grup whatsapp kepada siswanya, selanjutnya siswa diberikan tugas untuk materi pada hari tersebut dan dikumpulkan setiap hari jum'at ke sekolah dengan tetap mematuhi protokol kesehatan.

2. Setelah dilakukan pengujian menggunakan uji parsial (Uji T) diperoleh $t$ tabel nya 1,690, nilai t hitung $-0,348<\mathrm{t}$ tabel 1,690 dan nilai signifikansinya sebesar 0,730 > 0,05 maka dapat disimpulkan hasil uji T penelitian ini hipotesis H0 diterima dan Ha ditolak. Maka dapat disimpulkan bahwa tidak terdapat pengaruh yang signifikan pembelajaran PAI menggunakan aplikasi whatsapp terhadap prestasi belajar siswa di SD Negeri 14 Sitiung.

\section{Referensi}

Aji, Rizqon Halal Syah. (2020). Dampak COVID-19 Pada Pendidikan Di Indonesia: Sekolah, Keterampilan, Dan Proses Pembelajaran. Salam: Jurnal Sosial dan Budaya Syar-i.(7) 5: 395-402.

Aulia, S. (2020). Pembelajaran Daring Pada Masa Pandemi. 20 Juli.

Bilfaqih, Y., \& Qomarudin, M. N. (2015). Esensi Pengembangan Pembelajaran Daring (H. Rahmadhani \& D. W. Handayani (eds.)). Penerbit Deepublish.

Dewi, Wahyu Aji Fatma. (2020). Dampak Covid-19 Terhadap Implementasi Pembelajaran Daring Di Sekolah Dasar. Edukatif: Jurnal Ilmu Pendidikan 2(1): 55-61.

Muhibbin Syah. (2011). Psiklogi Belajar. Jakarta: Raja Grafindo Persada.

Mulyono Abdurrohman, (2003). Pendidikan bagi anak berkesulitan belajar. Jakarta : Rineka Cipta.

Mustofa, Mokhamad Iklil, Muhammad Chodzirin, Lina Sayekti, and Roman Fauzan. (2019). Formulasi Model Perkuliahan Daring Sebagai Upaya Menekan Disparitas Kualitas Perguruan Tinggi. Walisongo Journal of Information Technology 1(2): 151-60.

Nasional, Departemen Pendidikan. (2008). Kamus Besar Bahasa Indonesia (KBBI). Jakarta: Gramedia.

Pranajaya, P., \& Wicaksono, H. (2018). Pemanfaatan Aplikasi Whatsapp (Wa) Di Kalangan Pelajar: Studi Kasus Di Mts Al Muddatsiriyah Dan Mts Jakarta Pusat. Orbith: Majalah Ilmiah Pengembangan Rekayasa Dan Sosial, 14(1).

Sunendar, Dadang, dkk. (Tim Penyusun KBBI Edisi Kelima). (2020). Kamus Besar Bahasa Indonesia. Jakarta: Badan Pengembangan dan Pembinaan Bahasa, Kementerian Pendidikan dan Kebudayaan Republik Indonesia 